\title{
A Grandparent in the room: multiple family therapy for adolescents
}

\author{
Carol Smith*, Julie Potts, Kimberly Hoiles, Uli O'Sullivan \\ From 2014 ANZAED Conference: Driven Bodies Driven Brains \\ Fremantle, Australia. 22-23 August 2014
}

\section{Objective}

To provide a descriptive clinical perspective on the introduction and development of Multiple Family Therapy Groups for Day Patients and Outpatients at Princess Margaret Hospital, Perth Western Australia. Challenges will be discussed including motivation, integration and application with view to sharing with the audience the pitfalls and possibilities of this dynamic approach combining family and group therapies.

\section{Method}

Retrospective clinical perspectives, a composite case and literature review will be presented to highlight the exploration and evolution of a multiple family therapy groups.

\section{Discussion}

The focus of discussion will be on lessons learnt about the process of adapting clinical treatments within existing service frameworks including strategy for motivating and engaging both staff and patients in the process of change.

\section{Findings}

With creativity and collaboration, multiple family therapies can be integrated within existing treatment frameworks, research grants can facilitate the process of program development and extended families can become important treatment allies.

\section{Conclusion}

Multiple family therapy can be adapted to fit existing service frameworks and offers new possibilities for engagement with the adolescent and their wider family system. Grandparents, siblings, uncles and aunties are all resources in the treatment of an adolescent with an

\footnotetext{
* Correspondence: carol.smith2@health.wa.gov.au

Eating Disorders Program, Specialised Child and Adolescent Mental Health Service, Department of Health in Western Australia, Perth, Australia
}

eating disorder, and can offer alternative portals of hope and support in the recovery process.

Published: 24 November 2014

doi:10.1186/2050-2974-2-S1-P13

Cite this article as: Smith et al:: A Grandparent in the room: multiple family therapy for adolescents. Journal of Eating Disorders 2014 2(Suppl 1):P13.
Submit your next manuscript to BioMed Central and take full advantage of:

- Convenient online submission

- Thorough peer review

- No space constraints or color figure charges

- Immediate publication on acceptance

- Inclusion in PubMed, CAS, Scopus and Google Scholar

- Research which is freely available for redistribution

Submit your manuscript at www.biomedcentral.com/submit
() Biomed Central 